Endogami: Jurnal Ilmiah Kajian Antropologi

E-ISSN : 2599-1078

\title{
Kerajinan Batik dan Pewarnaan Alami
}

\author{
Alamsyah \\ Departemen Sejarah Fakultas Ilmu Budaya \\ Universitas Diponegoro Semarang - Indonesia \\ Email: alam_mahir@yahoo,com
}

\begin{abstract}
BATIK -- craft is a cultural heritage of Indonesia which existence keep growing each day. It is characterized by the existence of batik craft in various regions with their own characteristics. As a cultural heritage, batik craft had been around since the time of the kingdom era in our nation. Before the discovery of synthetic materials technology, batik coloration has always been using natural colors that are available in Indonesia. Natural coloration can be taken from tinggi wood, tegeran plant, teak leaf, indigo plant, secang, mahogany, and other plants. As the times progressed, natural coloring began to be replaced and abandoned by the craftsmen. Crafters use synthetic coloring starting in the early 20th century. Currently there is an awareness to return to the natural coloring because it is considered to be more environmentally friendly and cheaper. The use of natural coloring also pushes batik selling value higher when compared to the one using synthetic color.
\end{abstract}

Keywords: Handicraft, Batik, Coloration, Natural.

\section{Pendahuluan}

Eksistensi batik di Indonesia terkait dengan perkembangan kerajaan di nusantara hingga penyebaran ajaran Islam di tanah Jawa yaitu pada masa kerajaan Mataram, masa Kasunanan, dan masa Kasultanan. Setelah akhir abad ke-18 dan abad ke-19, perkembangan batik di Jawa cukup pesat. Pada saat itu batik yang dihasilkan adalah batik tulis. Penggunaan batik cap baru dikenal setelah perang dunia I atau sekitar tahun 1920an (Hariyana Nurainun, dkk, 2008: 124). Salah satu sumber daya alam di Indonesia yang dapat digunakan dalam kerajinan batik adalah zat pewarna alam (Maman Tocharman, tt: 1-2). Dalam perkembangannya, penggunaan bahan alam untuk pewarnaan batik sejalan dengan konsep pemanfaatan produk ramah lingkungan dengan memanfaatan sumber-sumber pewarna alami. Di beberapa negara seperti Jerman dan Belanda, telah dilakukan pelarangan penggunaan zat pewarna berbahan kimia sejak tahun 1996. Oleh karena itu, mulai bermunculan produk-produk tekstil yang menggunakan bahan pewarna alami, khususnya batik. Penggunaan batik berbahan pewarna alami merupakan pemanfaatan keanekaragaman hayati yang akan berdampak pada pelestarian kenakeragaman hayati dan pendapatan ekonomi masyarakat (Anak Agung Gede Rai Sedana, dkk, tt: 2).

Mendasarkan pada betapa pentingnya penggunaan bahan alami dalam pewarnaan batik, maka topik yang diangkat dalam artikel ini tentang "Batik dan Pewarnaan Alami". 
Endogami: Jurnal Ilmiah Kajian Antropologi

E-ISSN : 2599-1078

\section{Metode}

Metode penelitian yang dilakukan dalam menemukan dan mengumpulkan sumber atau informasi (heuristik) lebih mendasarkan pada sumber sekunder berupa kajian literatur atau pustaka (Garraghan, 1947: 34; Gottschalk, 1975: 32; Herlina, 2008: 17-24). Sumber sekunder tersebut diperoleh dari perpustakaan maupun dari browsing di internet. Sumber sekunder ini diperoleh dengan cara mencari dan mengumpulkan informasi atau bacaan dari berbagai sumber (Beni Ahmad Saebani, tt: 162-163). Sumber sekunder diperoleh dari buku, hasil penelitian, dan jurnal yang relevan dengan kajian ini. Sumber yang tersedia kemudian dilakukan kritik dan interpretasi. Tahapan selanjutnya adalah dilakukan klasifikasi, dihubung-hubungkan atau diakumulasikan antara data satu dengan yang lainnya, sebagai suatu bentuk interpretasi dan sintesa dalam rangka mererekonstruksi menjadi sebuah artikel.

\section{Pembahasan}

\subsection{Eksistensi Batik}

Kata batik merujuk pada kain dengan corak yang dihasilkan oleh bahan "malam" (wax) yang diaplikasikan ke atas kain, sehingga menahan masuknya bahan pewarna (dye), atau dalam bahasa Inggrisnya "wax-resist" (Siti Maziyah, dkk, 2015: 102). Batik berasal dari bahasa Jawa "mbatik" yang artinya membuat titik-titik. Jadi batik adalah karya dan sekaligus bentuk kegiatan yang dilakukan dengan bahan dasar kain yang diberi gambar dari titk-titik atau tetes-tetes yang berasal dari malam sebagai bahan penutupnya. Batik adalah kain yang dihiasi dengan gambar yang terbuat dari titik-titik yang membentuk garis yang dibuat dengan teknik resist menggunakan material lilin (malam). Motif batik dibuat dengan menggunakan alat yang disebut canting, yaitu alat sejenis pena yang terbuat dari bambu sebagai tangkainya, dan untuk tempat malamnya terbuat dari kuningan (Maman Tocharman, tt: 6-7; Heriyana Nurainun, dkk, 2008: 125). Batik adalah gambar pada mori yg dibuat dengan menggunakan alat bernama canting, yang menghasilkan batikan berupa macam-macam motif dan mempunyai sifat-sifat khusus yang dimiliki oleh batik itu sendiri (Irfa'ina Rohana Salma, 2013: 88). Standar Nasional Indonesia (SNI) No 08-0239 1989 mendefinisikan batik sebagai bahan tekstil hasil pewarnaan menurut corak khas batik Indonesia, dengan menggunakan lilin batik sebagai zat perintang.

Dalam konteks historis, asal usul batik salah satunya diduga berasal dari Sumeria yang kemudian dikembangkan di Jawa setelah dibawa oleh pedagang India. Saat ini batik bisa ditemukan di banyak negara seperti Indonesia, Malaysia, Thailand, India, Sri Langka, Iran, dan di beberapa negara benua Afrika. Walaupun demikian batik yang paling terkenal di dunia adalah batik yang berasal dari Indonesia terutama dari Jawa. Mungkin dikarenakan proses pembuatan yang rumit serta desainnya yang spesifik. Sebagai warisan budaya, batik merupakan karya yang dinamis dan dapat menyesuaikan dirinya baik dalam dimensi bentuk, ruang, dan waktu ((Heriyana Nurainun, 2008: 125; Anak Agung Gede Rai Sedana, $\mathrm{dkk}, \mathrm{tt}: 2)$. Batik sebagai identitas Indonesia telah dibuktikan dengan adanya penetapan batik 
sebagai warisan budaya tak benda milik bangsa Indonesia pada tanggal 2 oktober 2009 oleh UNESCO. Pengakuan terhadap batik ini diberikan karena pemerintah beserta rakyat Indonesia dinilai telah melakukan banyak langkah nyata untuk melindungi dan melestarikan batik secara turun temurun. Batik dinilai menyatu dengan denyut kehidupan masyarakat pendukungnya secara nyata dengan makna filosofis tentang kearifan hidup yang dalam (Anak Agung Gede Rai Sedana, dkk, tt: 2; Irfa'ina Rohana Salma, 2013: 87).

Pada dasarnya seni batik termasuk seni lukis dan merupakan salah satu seni kriya tekstil. Produk kerajinan batik telah dirasakan pada semua jenjang kehidupan masyarakat dan menjadi sarana hidup untuk mengangkat harkat dan martabat kehidupan, serta dijadikan sebagai mata pencaharian (Heriyana Nurainun, dkk, 2008: 124; Irfa'ina Rohana Salma, 2013: 88; Siti Maziyah, dkk, 2015: 102 ).

Dalam proses membatik, penempelan bahan perintang pada lembar kain merupakan langkah awal proses pembatikan. Cara membubuhkan malam batik pada lembar kain dikenal dengan beberapa cara antara lain dituliskan dengan menggunakan canting, dituliskan dengan menggunakan kuas dan dicapkan dengan menggunakan cap logam (tembaga). Cara yang pertama menghasilkan kain batik tulis, sedangkan cara yang kedua akan menghasilkan batik cap. Sebetulnya karya batik tulis dan batik dalam proses pewarnaannya sama. Namun demikian, batik tulis dianggap karya batik yang memiliki nilai yang lebih tinggi dari batik cap (Maman Tocharman, tt: 1).

Eksistensi batik yang saat ini ada di berbagai daerah pada dasarnya mendapatkan pengaruh pada masa kerajaan seperti pengaruh masa Majapahit. Batik yang mendapatkan pengaruh daerah tersebut antara lain Mojokerto yang meliputi daerah Kwali, Mojosari, Betero dan Sidomulyo. Daerah pembatikan yang mendapat pengaruh masa penyebaran Islam terdapat di di Ponorogo, baik berupa batik cap kasar atau batik cap mori biru. Adapun batik Solo dan Yogyakarta menyempurnakan corak batik yang ada di Mojokerto dan Tulung Agung, yang kemudian menyebar ke daerah Gresik, Surabaya dan Madura. Di daerah Jawa bagian barat, batik berkembang di daerah Banyumas, Pekalongan, Tegal dan Cirebon. Selain itu pembatikan juga dikenal di Jakarta dan Sumatera barat (Heriyana Nurainun, dkk, 2008: 124). Batik yang terdapat di daerah pesisir memiliki garis maskulin seperti terlihat pada corak "Mega Mendung", di mana di beberapa daerah pesisir pekerjaan membatik adalah lazim bagi kaum lelaki (Siti Maziyah, dkk, 2015: 103). Kerajinan batik di Indonesia tersebar di beberapa daerah di pulau Jawa yang kemudian menjadi nama dari jenis-jenis batik seperti batik Pekalongan, batik Lasem, batik Cirebon, batik Sragen, dan batik di daerah yang lain. Setiap batik dari daerah memiliki ciri motif yang spesifik (Heriyana Nurainun, dkk, 2008: 124).

Berdasarkan cara pelekatan lilin, batik bisa dibedakan menjadi menjadi 4 (tiga), yaitu batik tulis, batik cap, batik kombinasi (tulis dan cap), dan batik printing. Proses pembuatan keempat batik ini berbeda. Batik Tulis adalah batik yang diperoleh dengan cara menggunakan canting batik sebagai alat bantu untuk melekatkan lilin pada kain. Disebut batik tulis karena proses penggambaran motifnya, menggunakan tangan. Proses pembuatan batik tulis memakan waktu berminggu-minggu bahkan bulanan bila desain motifnya sulit. Harga jualnyapun relatif mahal, tergantung pada kerumitan proses pembuatannya. Tingkat kesulitan pengerjaan atau lama tidaknya pengerjaan menentukan harga batik. Batik Cap adalah batik yang diperoleh dengan cara menggunakan canting cap dari tembaga sebagai 
alat bantu untuk melekatkan lilin pada kain. Disebut batik cap karena motif batik dibentuk dengan cap, biasanya dibuat dari tembaga. Batik cap juga disebut dengan batik cetak. Pada perkembangannya, muncul jenis produksi sablon yaitu penggunanan klise atau hand print untuk mencetak motif diatas kain. Proses produksi yang menggunakan sistem cap ini, para pengrajin dapat menghasilkan produksi batik lebih banyak karena proses pembuatannya tidak terlalu lama. Batik Kombinasi adalah batik yang dihasilkan dari rangkaian kerja batik cap dikombinasikan dengan batik tulis. Pada perkembangan selanjutnya muncul jenis printing yaitu produksi batik melalui mesin. Jika dengan teknik tulis, produksi untuk satu kain batik tulis membutuhkan waktu yang lama, maka dengan mesin printing, sehari bisa menghasilkan puluhan bahkan ratusan kain batik. Oleh kalangan tertentu, batik printing dianggap merusak tatanan dalam seni batik karena proses pembuatannya tidak menggunakan proses pembuatan batik pada umumnya yaitu menggunakan lilin atau malam. Batik printing disebut sebagai kain bermotif batik. Alasan ekonomi dilakukan oleh pengusaha demi keuntungan bisnis tanpa memikirkan kelestarian batik asli dan mata pencaharian pembatik tradisional (Heriyana Nurainun, dkk, 2008: 126; Irfa'ina Rohana Salma, 2013: 87-88).

Batik Tulis, semula batik dibuat di atas bahan dengan warna putih yang terbuat dari kapas yang dinamakan kain mori, saat ini batik juga dibuat diatas bahan lain seperti sutera, poliester dan rayon serta bahan sintetis lainnya. Motif batik dibentuk dengan cairan lilin atau malam dengan menggunakan alat yang disebut dengan canting untuk motif halus atau kaus untuk motif besar. Kain yang telah dilukis dengan lilin kemudian dicelup dengan warna yang diinginkan, biasanya dimulai dengan warna-warna muda. Pencelupan dilakukan untuk motif lain dengan warna lebih tua atau gelap. Setelah beberapa kali proses pewarnaan, kain yang telah dibatik dicelupkan ke dalam bahan kimia atau bahan sintetis untuk melarutkan lilin (Heriyana Nurainun, dkk, 2008: 127-128).

\subsection{Pewarnaan Alami}

Ditinjau dari sumber diperolehnya zat warna tekstil dibedakan menjadi 2 (dua) yaitu zat warna sintetis dan zat warna alam. Zat pewarna sintetis adalah zat buatan (zat warna kimia). Warna sintesis merupakan pewarna yang dapat digunakan dalam suhu yang tidak merusak lilin, yang termasuk golongan pewarna tersebut adalah: indigosol, naphtol, rapid, basis, indanthreen, procion, dan lain lain (D. Pringgenies, 2013: 7). Kecenderungan menggunakan bahan pewarna kimia karena prosesnya jauh lebih mudah. Namun di sisi lain pengunaan pewarna sisntetis memunculkan masalah pencemaran lingkungan. Air sungai yang telah tercemar limbah pewarna sintetis batik dapat meresap ke sumur-sumur penduduk sehingga menurunnya kualitas kesehatan pada masyarakat. Kelemahan penggunaan bahan warna sintetis yang utama adalah limbah warna sintetis membahayakan kesehatan manusia dan meracuni lingkungan (Anak Agung Gede Rai Sedana, dkk, tt: 2; Maman Tocharman, tt: 2). Sejak 1 Agustus 1996 negara -negara maju, seperti Jerman dan Belanda, telah melarang penggunaan zat pewarna berbahan kimia.

Pemanfaatan zat pewarna alam untuk tekstil menjadi salah satu alternatif pengganti zat pewarna berbahan kimia. Adapun zat pewarna alami diperoleh dari alam yang berasal dari hewan (lac dyes) ataupun tumbuhan seperti dari akar, batang, daun, kulit dan bunga. 
Warna alami didapat dari bagian-bagian tumbuhan seperti akar, batang, kayu, kulit, daun dan bunga, atau dari getah buang (lac dye) binatang. Contoh warna alami antara lain tanaman tingi, jambal, tegeran, mahoni dan lain -lain. Bahan pewarna alami didapat dari pengolahan tumbuhan dan beberapa bahan alami lainnya (D. Pringgenies, 2013: 7; Irfa'ina Rohana Salma, 2013: 88). Bahan pewarna alami ini meliputi pigmen yang sudah terdapat dalam bahan atau terbentuk pada proses pemanasan, penyimpanan, atau pemrosesan. Beberapa pigmen alami yang banyak terdapat di sekitar kita antara lain: klorofil, karotenoid, tanin, dan antosianin. Pewarna alami umumnya aman dan tidak menimbulkan efek samping bagi tubuh ( (Endang Kwartiningsih, dkk, 2009: 41)

Warna alami untuk pewarnaan batik banyak diminati oleh konsumen dari mancanegara karena batik atau bahan yang menggunakan warna alam akan membuat sipenggunanya lebih nyaman dan dijamin tidak menimbulkan alergi. Timbulnya gerakan kembali ke alam, ketakutan akan pengaruh pencemaran oleh zat pewarna sintetis yang menyebabkan kanker dan adanya keinginan menghasilkan produk yang unik mendorong bangkitnya penggunaan zat pewarna alami (D. Pringgenies, 2013: 8).

Sebelum awal abad ke-20, pengrajin batik hanya membuat batik tulis yang menggunakan pewarna dari alam seperti jati, pohon mengkudu, soga, nila, tingi, tegeran, daun jati muda, dan lain-lain (Heriyana Nurainun, dkk, 2008: 126). Dalam proses membatik, pewarnaan kain adalah proses kedua setelah kain dibubuhi bahan perintang. Pada awalnya pewarnaan kain batik menggunakan pewarna alam yang bersumber dari berbagai jenis tumbuhan yang memiliki ekstrak warna sesuai yang dibutuhkan. Dalam perkembangannya, penggunaan warna alam sebagai pewarna batik sudah banyak ditinggalkan karena proses pembuatan warna alam memerlukan waktu yang panjang,warna alam tidak tahan lama disimpan sebelum proses pewarnaan, daya tahan warna alam cenderung mudah pudar. Proses pencelupan/pewarnaan memerlukan waktu yang panjang dan harus dilakukan berulang-ulang supaya menghasilkan warna yang lebih baik (Maman Tocharman, tt: 2).

Melihat kondisi di atas, sebenarnya dalam perjalanan perbatikan di Indonesia, proses penggunaan warna-warna alam dalam teknik batik ternyata sudah dilakukan oleh nenek moyang kita secara turun temurun (Maman Tocharman, tt: 2). Apalagi Indonesia sejak dulu hingga saat ini sebagai negara yang kaya akan sumber alam hayati dan banyak mengandung berbagai macam zat warna alami. Zat warna alam ini hasil ekstraksi dari daun, batang, kulit, bunga, buah, akar tumbuhan dengan kadar dan jenis colouring matter bervariasi sesuai dengan spesiesnya. Colouring matter adalah substansi yang menentukan arah warna dari zat warna alam, merupakan senyawa organik yang terkandung didalam zat warna alam. Bahan pembawa warna ada yang dapat digunakan secara langsung, dan ada yang harus melalui ekstraksi maupun fermentasi terlebih dahulu. Cara ekstraksi untuk memperoleh gugus pembawa warna sangat bervariasi dan akan berpengaruh terhadap warna yang ditimbulkan (Titiek Pujilestari, 2014: 2).

Proses ekstraksi pada semua bahan secara garis besar adalah sama yaitu mengambil pigmen atau zat warna yang terkandung dalam bahan. Perlakuan ekstraksi dengan cara pemanasan dengan merebus bahan pembawa zat warna alam menggunakan air adalah cara yang paling banyak dilakukan. Air yang ditambahkan untuk ekstraksi bahan pembawa warna jumlahnya tertentu dengan tujuan efisiensi dan untuk memperoleh ketuaan warna. Perebusan dilakukan hingga volume air menjadi setengahnya, apabila menghendaki larutan 
zat warna lebih kental, perebusan dapat dilanjutkan sehingga volume sisa perebusan menjadi sepertiga dari volume awal. Pewarnaan bisa dilakukan dengan dicoledkan atau dikuaskan tetapi yang paling umum adalah dengan pencelupan. Setelah pewarnarnaan selesai, pekerjaan selanjutnya adalah menghilangkan lilin dengan perebusan pada air mendidih sampai bersih. Hasilnya berupa kain bergambar. Gambar yang terbentuk dari garis dan variasi isian ornamentik itulah yang tadinya hasil torehan dengan lilin atau malam batik ((Titiek Pujilestari, 2014: 2; Irfa'ina Rohana Salma, 2013: 88).Warna dalam batik dihasilkan dari proses peresapan zat warna ke dalam serat-serat benang. Teknik pewarnaan antara lain: pencelupan, coledan, pelaburan dengan kuas, bahkan ada pembuat batik yang menggunakan teknik penyemprotan dengan spray gun untuk mewarnai karya-karya seni batik kreatifnya.

Pewarnaan kain menggunakan pewarna alami dengan menggunakan teknik celup rintang. Bagian kain menjadi bercorak karena pada waktu dicelupkan dalam cairan warna, terdapat bagian yang sengaja dirintangi. Bagian kain yang dirintangi itulah yang menimbulkan corak motif batik (Maman Tocharman, tt: 1). Timbulnya kesadaran untuk kembali ke alam (back to nature) dalam dunia batik terutama dalam penggunaan warnawarna alam adalah suatu indikasi yang menunjukkan adanya kesadaran dari fihak-fihak yang sering berkecimpung dalam perkembangan dunia industri batik. Paling tidak, dengan ditemukannya informasi tentang efek samping dari penggunaan warna sintetis yang menggunakan garam diazonium sebagai penyebab kanker yang ditemukan di negara maju seperti di Belanda dan Jerman. Larangan pemerintah Jerman terhadap penjualan produk tekstil yang menggunakan bahan kimia garam diazinon yang diperkirakan menyebabkan kanker, diikuti oleh pemerintah Belanda. Warna alam lebih aman dan ramah lingkungan. Warna alami merupakan peninggalan budaya leluhur sehingga perlu dilakukan (Maman Tocharman, tt: 8).

Pemilihan pewarna alami untuk mewarnai kain batik mulai berkembang. Diantara warna alam yang digunakan adalah dari ekstrak warna kulit buah mahoni yang menghasilkan warna coklat kekuning-kuningan dan tidak mudah luntur (Maman Tocharman, tt: 3; Yudi Satria, dkk, 2016: 101). Pewarnaan alam dari beberapa tanaman pembawa warna dewasa ini banyak digunakan oleh beberapa industri batik dan tekstil kerajinan karena bahan bakunya tersedia disekitar perajin. Arah warna adalah hasil warna alam untuk pewarnaan batik yang dapat mengikat sekaligus mewarnai material (kain katun dan sutera). Daun jati Dapat dijadikan sebagai pewarna alami karena dapat menghasilkan warna coklat. Warna biru, ungu, violet, magenta, merah, dan oranye juga dapat diperoleh pada bagian tanaman seperti buah, sayuran, bunga, daun, akar, dan umbi (Yudi Satria, dkk, 2016: 102). Jenis-Jenis tumbuhan yang digunakan sebagai sumber pewarna alami, diantaranya untuk warna merah sebagai sumber pewarna alaminya dari tingi dan secang.Untuk tanaman tingi, bagian yang dimanfaatkan adalah pada bagian kulit kayu bagian luar, sedangkan untuk secang bagian yang digunakan adalah pada bagian inti kayu. Adapun warna Biru, tumbuhan yang menghasilkan warna biru adalah tom/indigo. Bagian tom yang dimanfaatkan adalah daunnya. Untuk warna Kuning, tumbuhan yang digunakan sebagai sumber pewarna alam adalah jelawe dan delima. Bagian yang diambil dari kedua tumbuhan ini adalah pada bagian kulit buahnya (Anak Agung Gede Rai Sedana, dkk, tt: 7). Selain tanaman di atas ada juga warna alam yang dapat dipergunakan sebagai pewarna batik 
antara lain adalah: jambal (Peltophorum pterocarpum Back), temu lawak (Cucurma xanthorrhiza Toxb) sebagai penghasil warna coklat, akar mengkudu (Morinda citritolia. L) dan daun teruntum (Lumritzeralittore) menghasilkan warna merah, daun pohon nila (indigofera), kulit soga tingi (Ceriops candolleana arn), kayu tegeran (Cudraina javanensis), kunyit (Curcuma), teh (The), kulit soga jambal (Pelthophorum ferruginum), kesumba (Bixa orelana), dan daun jambu biji (Psidium guajava) (D. Pringgenies, dkk, 2013: 8; Prima Astuti Handayani, dkk, 2013: 2).

Beberapa kendala pada pewarnaan batik yang menggunakan zat warna alam antara lain prosesnya tidak praktis karena diperlukan proses pencelupan berulangulang, ketersediaan variasi warnanya agak terbatas hanya untuk warna-warna cerah, dan ketersediaan bahannya yang tidak siap pakai. Hal inilah yang membuat diperlukannya proses-proses dan formulasi khusus agar pewarna alami dapat dijadikan sebagai pewarna batik yang berkualitas. Di bawah ini produk batik yang menggunakan pewarnaan alami sebagai berikut:

Gambar 1. Koleksi Ir. Ita Riniatsih, M.Si Undip 2018

Kayu tingi (Ceriops candolleana) yang menghasilkan arah warna cokelat (Https://www.scribd.com/doc/56551734/Pewarna-Alami-Batik-Dari Secang-Tingi-Dan-Tegaran).

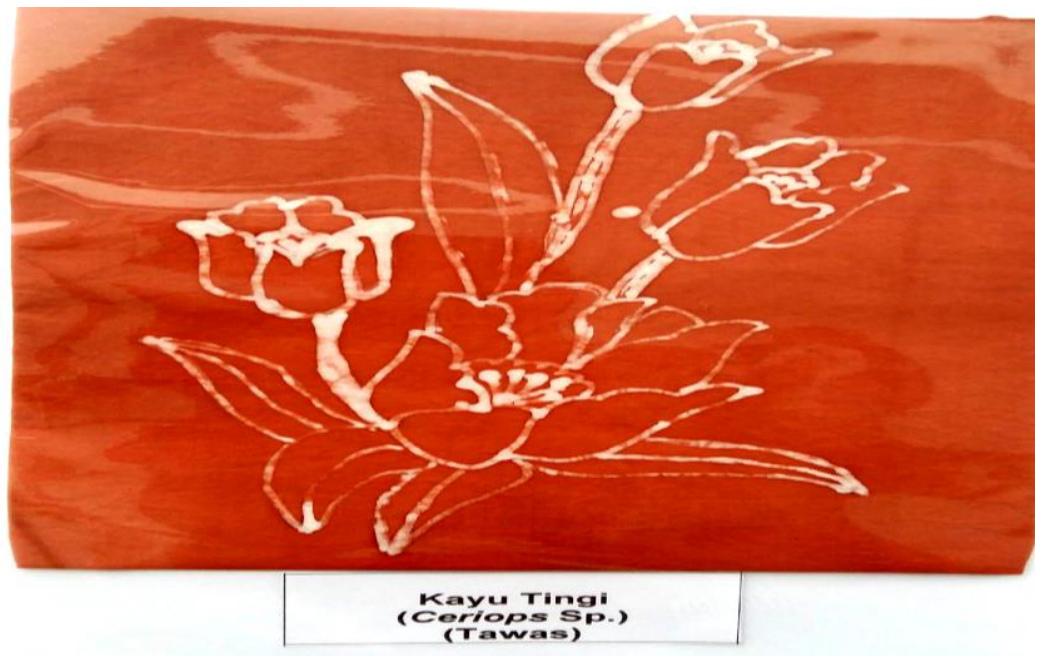

Gambar 2. Koleksi Ir. Ita Riniatsih, M.Si Undip 2018

Kayu tegeran (Maclura cochinchinensis) yang menghasilkan arah warna kuning (https://www.scribd.com/doc/56551734/Pewarna-Alami-BatikDari Secang-Tingi-Dan-Tegaran). 
Endogami: Jurnal Ilmiah Kajian Antropologi

E-ISSN : 2599-1078

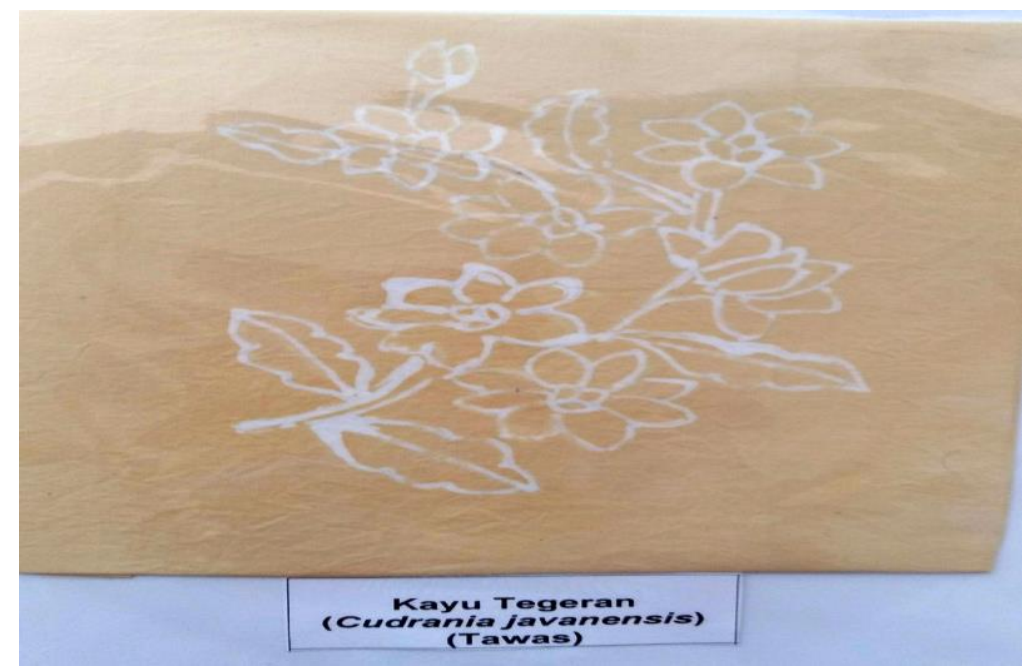

Gambar 3. Koleksi Ir. Ita Riniatsih, M.Si Undip 2018

Kayu secang (Caesalpia sappan) yang cenderung mengarah ke warna merah.

Selain dijadikan bahan minuman, kulit kayu secang juga dapat digunakan sebagai warna alami batik yang menghasilkan warna merah

(https: / / www.scribd.com / d oc/56551734/Pewarna-Alami-Batik-Dari Secang-Tingi-Dan-Tegaran; http://batik.or.id/bahan-pewarna-alam-buat-batik/.)

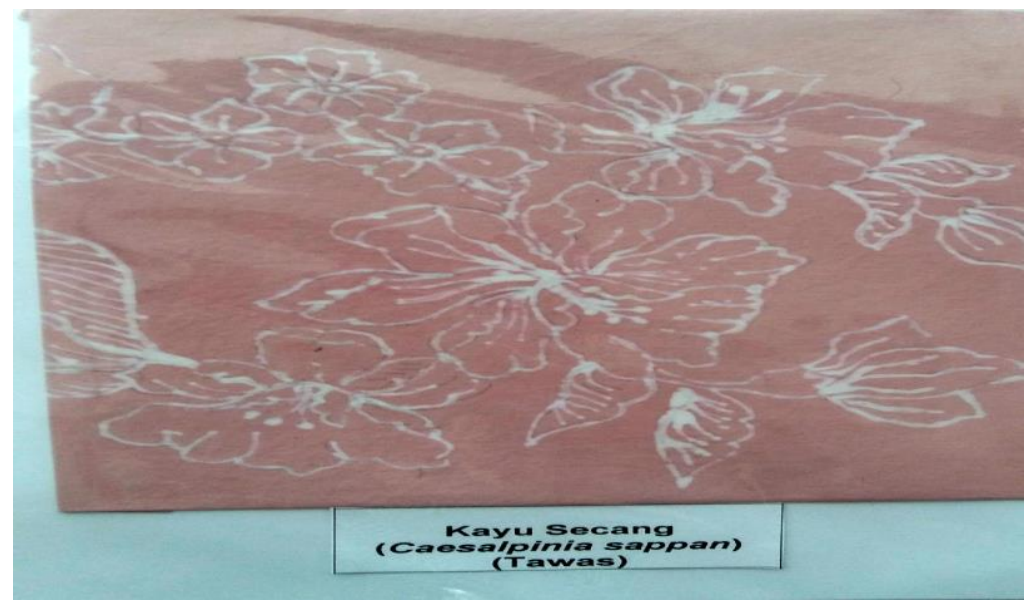

Gambar 4. Koleksi Ir. Ita Riniatsih, M.Si Undip 2018

Daun muda jati dapat menghasilkan warna merah kecokelatan pada batik (http://batik.or.id/bahan-pewarna-alam-buat-batik/) 


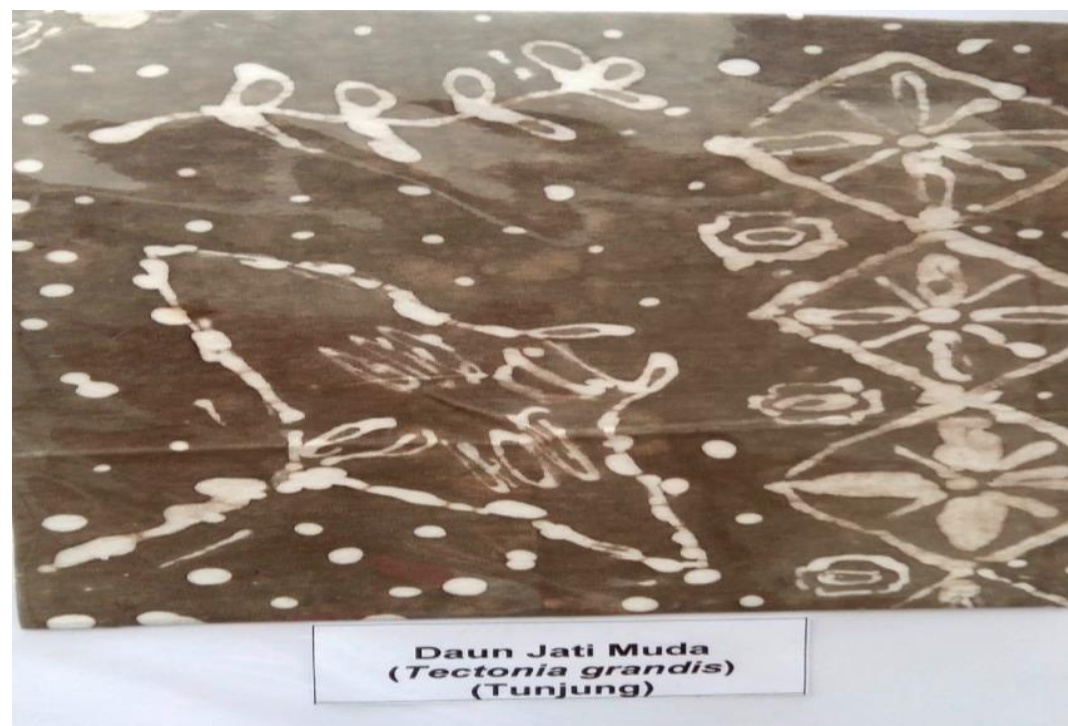

Gambar 5. Koleksi Ir. Ita Riniatsih, M.Si Undip 2018

Pohon Indigo, biasanya kita mengenal pohon ini dengan nama Pohon Tarum atau Nila. Dari tanaman ini dapat memanfaatkan daunnya sebagai bahan pewarna alami batik untuk menghasilkan warna biru (https://obatrindu.com/bahan-pewarna-alami-batik/)

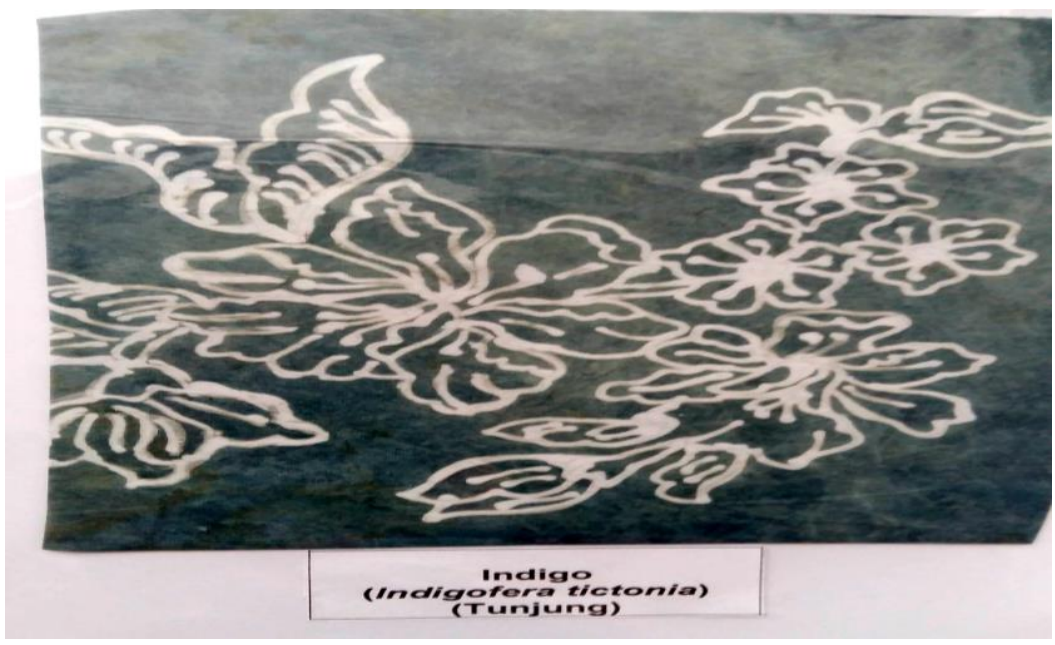

Gambar 6. Koleksi Ir. Ita Riniatsih, M.Si Undip 2018

Salah satu bahan yang dapat digunakan sebgai zat warna alami adalah kulit kayu mahoni (Swietenia mahagoni (L.) Jacq). untuk mendapatkan warna merah kecoklatan

(http://www.academia.edu/6241945/Pewarna_Alam_dari_Kulit_Kayu_Mahoni) 
Endogami: Jurnal Ilmiah Kajian Antropologi E-ISSN : 2599-1078

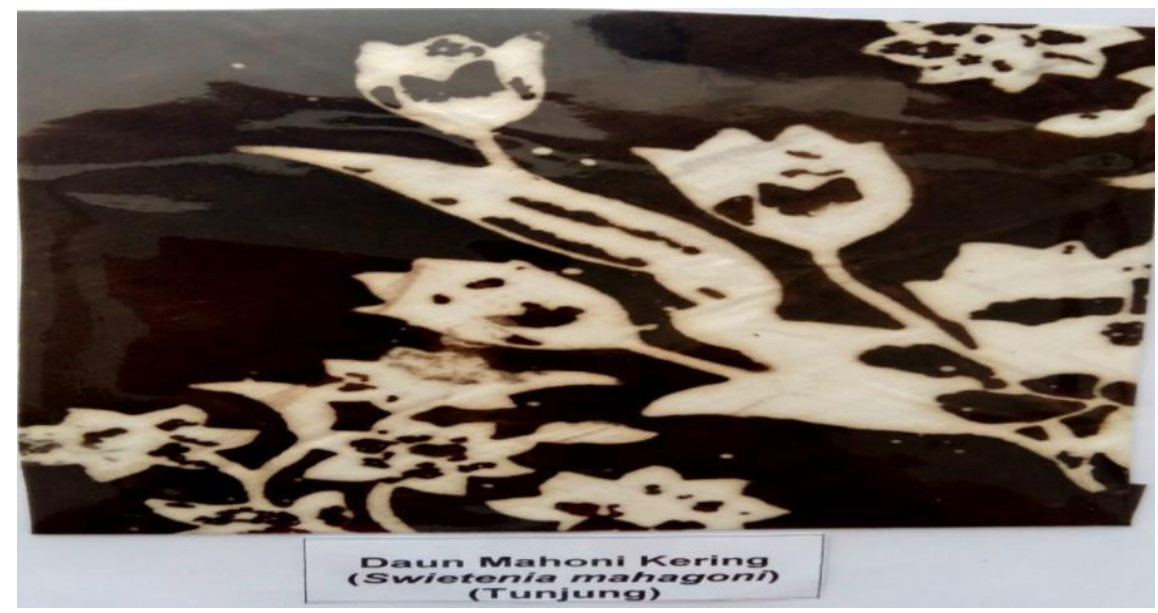

Gambar 7. Koleksi Ir. Ita Riniatsih, M.Si Undip 2018 Campuran antara warna merah dan biru

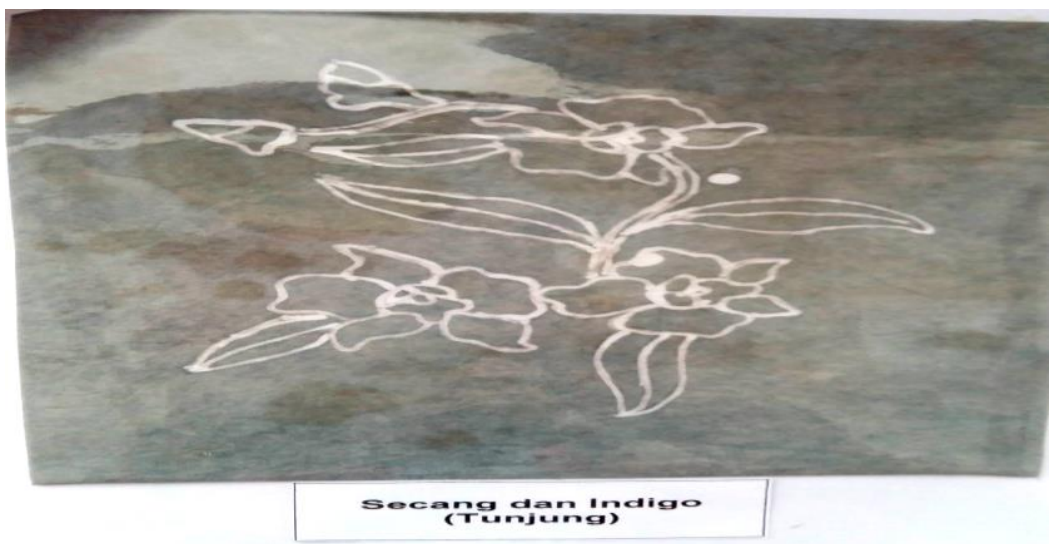

Gambar 8. Koleksi Ir. Ita Riniatsih, M.Si Undip 2018 Warna yang dihasilkan antara campuran warna Kuning dan biru 


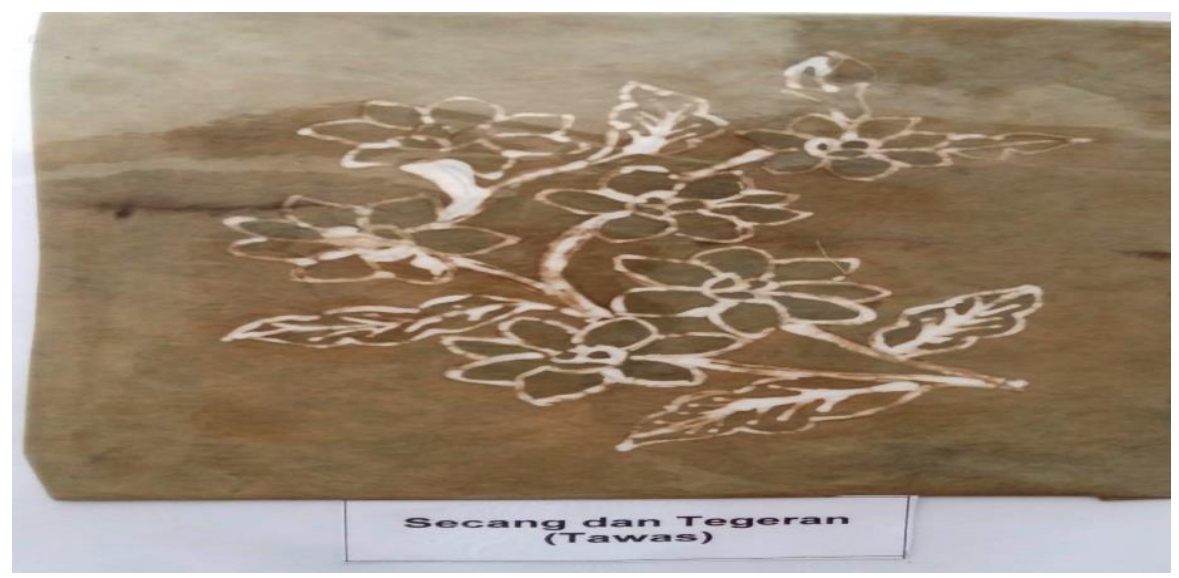

Gambar 9. Koleksi Ir. Ita Riniatsih, M.Si Undip 2018

Warna hitam atau coklat, tergantung fiksasinya (Dana Kurnia Syabana, dkk, 2013: 52)

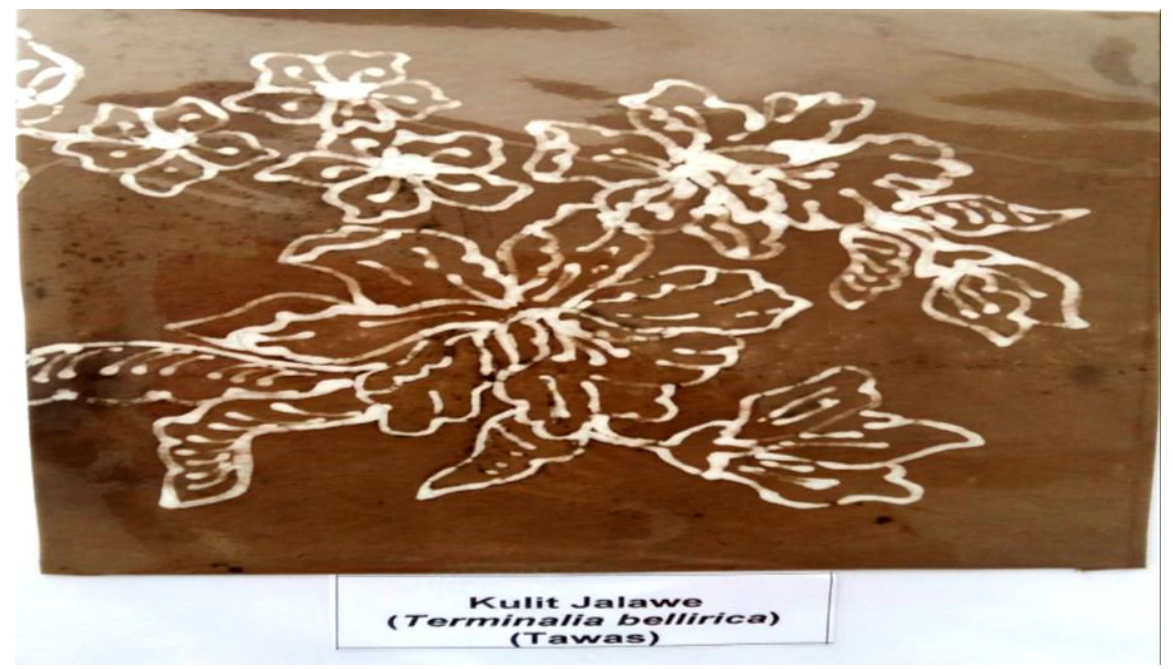

\section{Simpulan}

Batik sebagai kerajinan masyarakat Indonesia telah diakui dunia sebagai world heritage (warisan dunia). Batik tidak hanya menjadi budaya masyarakat tetapi juga berkontribusi dalam menggerakkan ekonomi masyarakat juga terlihat dengan hadirnya klaster-klaster batik di berbagai daerah. Seiring dengan adanya kesadaran lingkungan, kesehatan, tuntutan pasar, dan kesediaan bahan baku muncul gerakan perubahan dalam penggunaan pewarnaan batik. Perubahan tersebut adalah beralihnya penggunaan warna sintesis menjadi pewarnaan alami. Pewarnaan ini diambil dari berbagai jenis tanaman yang tumbuh. Melalui pewarnaan alami dalam kerajinan batik, maka pencemaran lingkungan dapat diminimalisir, pangsa pasar lokal dan internasional semakin terbuka, serta harga jual batik lebih tinggi. Bahkan dengan adanya kecenderungan penggunaan bahan alami dalam batik, memunculkan jenis 
Endogami: Jurnal Ilmiah Kajian Antropologi

E-ISSN : 2599-1078

usaha baru yaitu hadirnya penjualan yang menyediakan bahan baku alami di berbagai tempat dengan harga yang relatif lebih murah.

\section{Daftar Pustaka}

Badan Standardisasi Nasional. 2010. SNI ISO 105 - C06 : 2010.

Garraghan, Gilbert J. 1947. A Guide to Historical Method. New York: Fordham University Press.

Gottschalk, Louis. 1975. Mengerti Sejarah. Terjemahan Nugroho Notosusanto. Jakarta: Yayasan Penerbit Universitas Indonesia

Handayani, Prima Astuti, dan Ivon Maulana. 2013. Pewarna Alami Batik Dari Kulit Soga Tingi (Ceriops Tagal) dengan Metode Ekstraksi. Jurnal Bahan Alam Terbarukan (JBAT) Vol 2 No 2 (2013)1-6, hlm. 2. Dalam https://journal.unnes.ac.id/nju/index.php/jbat/article/view/2793/2846

Herlina, Nina. 2008. Metode Sejarah. Bandung: Satya Historika.

I Wayan Sudiarta, Anak Agung, I Wayan Sudiarta, Jajang Suryana. tt. Pewarna Batik Alami Di Tjok Agung Indigo Desa Pejeng Kecamatan Tampaksiring Kabupaten Gianyar. Universitas Pendidikan Ganesha Singaraja Indonesia. Dalam https:/ / ejournal.undiksha.ac.id/index.php/JJPSP/article/view/4715/3586

Kwartiningsih, Endang, Dwi Ardiana Setyawardhani, Agus Wiyatno, dan Adi Triyono, 2009. Zat Warna Alami Tekstil Dari Kulit Buah Manggis. Jurnal Ekuilibrium Vol. 8. No. 1. Januari 2009, hlm. 41-45. Dalam Https:/ Eprints.Uns.Ac.Id/700/1/Zat_Warna_Alami_Tekstil_Dari_Kulit_Buah_Mang gis.Pdf).

Maziyah, Alamsyah, Indrahti. 2015. Ornamen Mantingan. Semarang: Museum Ranggawarsita Jawa Tengah.

Nurainun, Heriyana, dan Rasyimah. 2008. Analisis Industri Batik Di Indonesia. Jurnal Fokus Ekonomi (FE), Vol.7, No. 3 Desember 2008, hlm. 124-135. Dalam https://Scholar.Google.Com/Scholar?Hl=En\&As_Sdt=0\%2c5\&Q=Batik+dengan+baha n+alami\&btnG

Pringgenies, D., E. Supriyantini, R. Azizah, R. Hartati. 2013. Aplikasi Pewarnaan Bahan Alam Mangrove Untuk Bahan Batik Sebagai Diversifikasi Usaha Di Desa Binaan Kabupaten Semarang. Jurnal Info LPPM Edisi XV, Nomor 1, Pebruari 2013, hlm. 7. Dalam Https:/ /Ejournal2.Undip.Ac.Id/Index.Php/Info/Article/View/1282/968 
Endogami: Jurnal Ilmiah Kajian Antropologi

E-ISSN : 2599-1078

Pujilestari, Titiek. 2014. Pengaruh Ekstraksi Zat Warna Alam Dan Fiksasi Terhadap Ketahanan Luntur Warna Pada Kain Batik Katun (The Effect Extraction Method And Fixation Of Natural Dyes To Color Fastness On Cotton Fabric). Jurnal Dinamika kerajinan dan Batik, Vol. 31. No. 1 Juni 2014, hlm. 2.

Riniatsih, Ita, Wahyu Krisna Hidayat, Alamsyah. 2017. Aplikasi Pemanfaatan Pewarnaan Alami Ramah Lingkungan untuk Pewana Batik. Materi Pengabdian Masyarakat di Grobogan, Tim LPPM Undip 2017

Saebani, Beni Ahmad. tt. Metode Penelitian, Bandung: Pustaka Setia

Salma, Irfa'ina Rohana. 2013. Corak Etnik Dan Dinamika Batik Pekalongan (Ethnic Pattern and Dynamics Pekalongan Batik). Jurnal Dinamika kerajinan dan batik Vol. 30 No. 2 tahun 2013, hlm. 87-89. Dalam https://Media.Neliti.Com/Media/Publications/59202-Id-CorakEtnik-Dan-Dinamika-Batik-Pekalonga.Pdf $\backslash$

Satria, Yudi dan Dwi Suheryanto. 2016. Pengaruh Temperatur Ekstraksi Zat Warna Alam Daun Jati Terhadap Kualitas dan Arah Warna Pada Batik (The Effect of Natural Dyes Teak Leaves Extraction Temperature to the Quality and Color Direction in Batik). Jurnal Dinamika Kerajinan dan Batik Vol. 33 No. 2 Tahun 2016, hlm. 101-102. Dalam https:/ / media.neliti.com/media/publications/59538-ID-pengaruh-temperaturekstraksi-zat-warna.pdf

Syabana, Dana Kurnia, Yudi Satria, Retno Widiastuti. 2013. Aplikasi Zat Warna Alam Pada Tenunan Serat Doyo Untuk Produk Kerajinan (Application Natural Dyestuff on Woven Fibers Doyo For Handicraft Product). Jurnal Dinamika Kerajinan dan Batik Volume 30 No. 1. Juni 2013, hlm. 52. Dalam https://media.neliti.com/media/publications/61049-IDaplikasi-zat-warna-alam-pada-tenunan-ser.pdf

Tocharman, Maman. Tt. Eksperimen Zat Pewarna Alami Dari Bahan Tumbuhan Yang Ramah Lingkungan Sebagai Alternatif Untuk Pewarnaan Kain Batik. Dalam hhttp:/ /File.Upi.Edu/Direktori/Fpsd/Jur._Pend._Seni_Rupa/194811251974121Maman_Tocharman/Proposal_Penelitian_3_File_13.Pdf). Hal. 1).

https://www.scribd.com/doc/56551734/Pewarna-Alami-Batik-Dari Secang-Tingi-Dan-Tegaran. Dikunjungi 21 Mei 2018

http://batik.or.id/bahan-pewarna-alam-buat-batik/. Dikunjungi 21 Mei 2018

http://www.academia.edu/6241945/Pewarna_Alam_dari_Kulit_Kayu_Mahoni. Dikunjungi 21 Mei 2018 